\title{
Cyanoprokaryota cultivation with the lighting unit under different light regimes
}

Petrukhina D.I.

Russian Institute of Radiology and Agroecology, Obninsk, Russia

E-mail: daria.petrukhina@outlook.com

Key message. The continuous phototrophic growth and light / dark cycled regime showed comparable OTR, max. $\mu$ 0.06 $h^{-1}$, biomass concentration ca. $0.8 \mathrm{~g} \cdot \mathrm{L}^{-1}$. During growth with $1.5 \mathrm{~g} \cdot \mathrm{L}^{-1}$ glucose compared to the phototrophic showed the higher OTR.

Keywords: cyanobacteria, photobiotechnology, Limnospira

The cultivation of cyanoprokaryota in Device for Sterile Online Measurement system: light distribution over the shake flask bottom and Limnospira strain PCC 9108 (earlier Arthrospira (Nowicka-Krawczyk et al. 2019)) were maintained in Zarrouk medium. The light intensity of $180 \mu \mathrm{mol} \mathrm{m}^{-2} \mathrm{~s}^{-1}$ measured via Li-Cor Quantum Sensor for photosynthetic active radiation 400$700 \mathrm{~nm}$. Specific growth rate $(\mu)$ calculated during time interval of exponential growth from biomass concentration

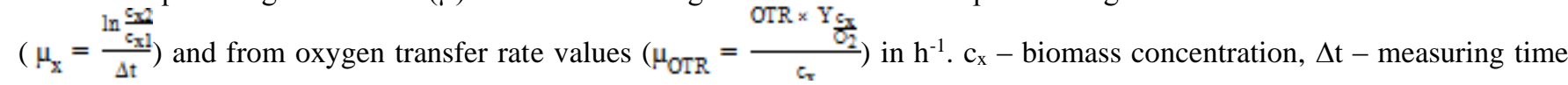
interval; yield

coefficient for biomass per oxygen $\mathrm{Y}_{\frac{\mathrm{S}_{\mathrm{x}}}{\mathrm{O}_{2}}}=0.5076 \frac{\mathrm{Ex}_{\mathrm{x}}}{\mathrm{g}_{02}}$ respectively to (Vonshak, 1997); OTR - oxygen transfer rate $\left(\mathrm{g}_{\mathrm{O} 2} \mathrm{~L}^{-1} \mathrm{~h}^{-1}\right)$

as and carbon transfer rate automatically calculated by online monitoring photosynthetic unit. Dry biomass concentration $\mathrm{c}_{\mathrm{x}}$ $\left(\mathrm{g}_{\mathrm{x}} \cdot \mathrm{L}^{-1}\right)$ determined via OD at $750 \mathrm{~nm}$ of the cell suspension. Correlation of OD and dry biomass concentration advance performed as $\mathrm{c}_{\mathrm{x}}=\mathrm{OD}_{750 \mathrm{~nm}} \cdot 0.82 \mathrm{~g} \cdot \mathrm{L}^{-1}$ respectively to (Petrukhina, Lykov 2018).

The cultivation with the lighting unit under different light regimes obtained: Specific growth rate $\mu\left(\mathrm{h}^{-1}\right): 0.06 / 0.054$ to continuous phototrophic and $0.058 / 0.055$ to $16 \mathrm{~h} / 8 \mathrm{~h}$ light / dark cycled phototrophic. Minim. OTR $-1.5 \mathrm{mmol} \mathrm{L}^{-1} \mathrm{~h}^{-1}$. The total oxygen transfer $\left(\mathrm{mmol} \cdot \mathrm{L}^{-1}\right): 80$ to continuous phototrophic, 50 to $16 \mathrm{~h} / 8 \mathrm{~h}$ light / dark cycled phototrophic and 60 to continuous photomixotrophic. The biomass related oxygen production in mmol $\mathrm{O}_{2} \mathrm{~g}_{\mathrm{x}}^{-1} \mathrm{~h}^{-1}: 0.18$ to continuous phototrophic and 0.20 to $16 \mathrm{~h} / 8 \mathrm{~h}$ light / dark cycled phototrophic. The obtained specific growth rate $\mu$ for phototrophic cultivated was in the range of values reported in literature for cyanoprokaryota suitable light intensity: $0.051 \mathrm{~h}^{-1}$ (Tomaselli et al. 1997); $0.048 \mathrm{~h}^{-}$ ${ }^{1}$ (Vonshak 1997); $0.058 \mathrm{~h}^{-1}$ (Xue et al. 2011).

The investigated cells able growed fully photosynthetically under the implemented warm white LED. OTR showed an

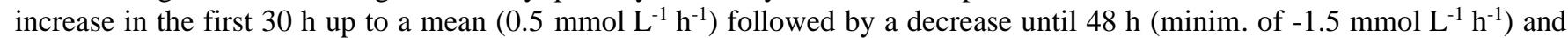
then increased again to a value of ca. $-0.5 \mathrm{mmol} \mathrm{L}^{-1} \mathrm{~h}^{-1}$. The carbon dioxide transfer rate showed little deviation from 0 because produced carbon dioxide during respiratory activity was immediately dissolved in the liquid strong alkaline Zarrouk medium of $\mathrm{pH}$ and not emitted to the gas phase. The oxygen transfer showed an cells oxygen consumption of $18 \mathrm{mmol} \cdot \mathrm{L}^{-1}$ and photosynthetic production of overall $80 \mathrm{mmol} \cdot \mathrm{L}^{-1}$. The oxygen transfer decelerated from 48 to $80 \mathrm{~h}$ cultivation, then a linear decline was observed.

To detect cells photosynthetic behaviour under changing light regime was applied a light / dark cycle. OTR during the dark period a close to zero (oxygen transfer at constant level) and during the light period - as under continuous light. OTR dropped down after $64 \mathrm{~h}$ cultivation to a minimum of $-1.5 \mathrm{mmol} \mathrm{L}^{-1} \mathrm{~h}^{-1}$ when biomass concentration reached approx. $0.2 \mathrm{~g} \cdot \mathrm{L}^{-1}$.

Photomixotrophic regime has been applied and Zarrouk medium was supplemented with a suitable glucose concentration (1.5 $\mathrm{g} \cdot \mathrm{L}^{-1}$ ) (Vonshak 1997; Chojnacka, Zielinska 2012). At the cultivations beginning the photomixotrophic culture showed a higher OTR than the phototrophic and then - a lower decrease until $48 \mathrm{~h}$ cultivation to minim. $-1.5 \mathrm{mmol} \mathrm{L}^{-1} \mathrm{~h}^{-1}$ than phototrophic with $-2.0 \mathrm{mmol} \mathrm{L}{ }^{-1} \mathrm{~h}^{-1}$. Glucose residual concentration was approx. $1 \mathrm{~g} \cdot \mathrm{L}^{-1}$. Consequently, it was not consumed completely.

Chojnacka K, Zielinska A. 2012. Evaluation of Growth Yield of Spirulina (Arthrospira) Sp. in Photoautotrophic,

Heterotrophic and Mixotrophic Cultures. World J. Microbiol. Biotechnol. 28: 437-445.

Molina Grima E et al. 1999. Photobioreactors: Light Regime, Mass Transfer, and Scaleup. J. Biotechnol. 70: $231-247$.

Nowicka-Krawczyk P et al. 2019. Detailed characterization of the Arthrospira type species separating commercially grown taxa into the new genus Limnospira (Cyanobacteria). Scientific reports. 9(1): article Nr: 694.

Petrukhina DI, Lykov IN. 2018. Cryopreservation of cyanobacteria Arthrospira platensis. Tekhnologii zhivykh sistem [Technologies of Living Systems] 15(1): 49-54 (in Russian)

Posten C. 2009. Design Principles of Photo-Bioreactors for Cultivation of Microalgae. Eng. Life Sci. 9: 165-177.

Tomaselli L et al. 1997. Physiological Behaviour of Arthrospira (Spirulina) maxima during Acclimation to Changes in Irradiance. J. Appl. Phycol. 9: 37-43.

Vonshak A. 1997. Spirulina Platensis (Arthrospira): Physiology, Cell-Biology and Biotechnology, Taylor \& Francis, London: 252.

Xue S et al. 2011. Growth of Spirulina platensis Enhanced Under Intermittent Illumination. J. Biotechnol. 151: 271-277. 